\title{
The regulation of work activity and the new labor and production contexts
}

\author{
Elaine Cristina Silva ${ }^{\mathrm{a} *}$ and Paulo Eduardo Gomes Bento ${ }^{\mathrm{a}}$ \\ Industrial Engineer Department, Federal University of São Carlos, Rodovia Washington Luis, km 235, SP, Brazil.
}

\begin{abstract}
In recent decades, there has been a rise in the use o lean production model techniques. Through this approach, companies become more flexible, a fact that increases the interest in studies regarding the introduction of this model in businesses and its impacts on working conditions. Important observations concerning ergonomics, such as the theme of work activity regulation, have been highlighted in such studies. This article aims to discuss strategies and regulations adopted by the workers on assembly lines that are considered flexible. The article presents the results of a study in a company that adopts some lean production techniques. The study was analyzed using the activity analysis as one of the premises of the Ergonomic Work Analysis (EWA). Many aspects of the traditional assembly line remain present in the scenario that was studied, however a new language was employed and aspects in the nature of regulations demonstrate that the relation with lean production techniques influence the operators' operational modes.
\end{abstract}

Keywords: organizational transformations, lean production, regulation of work activity, ergonomics

\section{Introduction}

The world of labor has been transformed due to changes in the production of goods and services and due to the incorporation of technology, a fact that has attracted the attention of numerous researchers. The global economic and social changes have profoundly altered the production systems, resulting in a transition from the process of mass accumulation to flexible accumulation [12]. One of the new forms of production management in companies in this new stage of production is lean production. Through this approach to management, companies that adopt lean production become more flexible, adopt new principles and new techniques in production management as well as in the management of workforces, supported upon the motivation of the workers as they perform their activities, upon team-work, and stimulated by qualification (versatility), multifunctionality and engagement at work.

While some authors associate their methods with a greater participation of the operator, teamwork and an increased range of skills needed for a greater con- trol over the work process [18]. Others, relate the new model with the exploitation of the worker's mental workload as well as the intensification of the work itself [9]. There are different views, having as a starting point a collection of data gathered by several authors who have studied the model of flexible production [14].

Ergonomics considers that changes in the regulatory areas cause the workers to implement strategies and operational methods in order to regulate their internal state and achieve the results expected by the organization [8]. Therefore, these technical and organizational changes can influence the final results related to health and production.

This article aims, therefore, at presenting some strategies and regulations adopted by workers in a flexible assembly line during their work activities. In order to achieve this, a case study was conducted in an assembly line of a company that adopts some techniques and tools of the lean production model. The study was analyzed, using the activity analysis method, based on the assumptions of Ergonomic Work Analysis that employs qualitative methodolo-

\footnotetext{
* Corresponding author e-mail: elainegpec@gmail.com
} 
gies of the observant type, through which a detailed description of the actual behavior of the individuals becomes possible since the situations and the time in which work activity occurs is maintained [10].

\section{The transformation of work organization}

The industry, especially the automotive industry, presented three basic organizational phases: "handicraft", answering to the product demands of the more fortunate classes, then "mass production", which granted this market access to the general population. In the 1970s this model slipped into crisis due to its organizational rigidity and inability to respond to changing market demands. The "lean production model" is what is being adapted to the present [18].

The lean production model is meant to organize that which is produced, it causes changes in organization and in work relations, being that a "flexible" company presupposes, as a consequence, an "increased flexibility" in the workforce [1].

The paradigm of flexible production is widespread, especially in businesses, important consequences in the relations between capital and labor were generated. Therefore, the lean production model emerged along with a concept of work organization which is very characteristic of the model [17].

Lean production involves, among other factors, reduced waste, improved product quality, reduced inventory, reduced downtime, lower costs, greater information flow and flexibility. In this context there is need for the involvement of motivated workers, since they are the ones who are responsible for organizational development $[7,18]$.

The base of the Japanese model is group work, in a more cooperative manner. In this model, the quality control circles (QCC) are one of the work mechanisms which are intergraded to the organizational logic of the Japanese model [6].

To the lean production system is not the individual, but the team that forms the basic unit of work process. This form of organization goes beyond partaking from the knowledge and motivation of the employees, it outsources indirect personnel and control personnel, such as the ones responsible for cleaning, logistics and others. A reduction in the differences between hierarchical levels is sought, thus guaranteeing structures with more horizontal characteristics [9].

Qualification in lean production is a controversial issue, but he concludes that the logic of Japanese work organization is guided by two simultaneous aspects: a) minimizing the porosity of the process, "multitasking" and b) transfering activities that are denominated as elements of "everyday life engineering", "multi-qualification", to the workers on the factory's floor [19].

In the model that was studied, workers cease to be "specialized" in performing a task, to become "multifunctional", they must be able to perform a multitude of tasks [1].

The term multivalent carries a sense of positive value, but he stresses that it is necessary to examine the true extent of productive organization and the content of the work. Multivalent means more varied, without implying, however, a significant change in the contents of tasks, that is, the work does not necessarily need to be more intellectual, even if one is to work more complex machinery [13].

Even while taking into account that the main interest companies have when adopting new patterns of work have to do with the economic realm of things, it is possible to conclude that these changes have direct implications on the daily life of workers [1].

According to some studies on the perception of employees, the adoption of lean production model as a way of organizing production and work, while facilitating the implementation of certain tasks and or relieving the workload, allowing for the involvement and participation also brought impositions related to the increased pace of work.

\section{The regulation of work activity}

Regulation is a broad topic, which involves several conceptual theories: legal theories, economic theories, political theories and sociological theories. In this article, the field of sociological theory will be described.

The social theory of regulation, which can in principle cover the social field in its entirety, can also be restricted to a specific field, such as work. This research is directed to aspects of work activity.

In this context, regulate work is to establish the conditions in which the work process can be fulfilled. Thus, the regulation extends from the formalizations that dictate work to the more concrete content of such formalizations. Economic, social, institutional, material and immaterial conditions form a structure through which work is done. This theory is related to the construction of the identity of individuals, among these, workers, and their individuality [2]. 
The concept of regulation allows for the analysis of the relations built around different forms of work, as well as allowing one to become familiar with the theme of absence or lack of work [2].

The social theory of regulation of work, which can in principle cover the whole social field concerning this issue, may also restrain itself to the specific field of fulfillment, by the worker, of his activity within the work organization. This is the focus of this article, based on the theory of activity ergonomics.

The concept of regulation is used in ergonomics according to the object with which the regulation coincides: 1) the regulation of a system in which the operator plays the role of one who compares and regulates a technical system, 2) the regulation of human activity itself, in which the operator regulates his own work activity in order to avoid the activities' negative repercussions on the internal state, accomplishing the final results or goals of the task, or learning [4].

The results in work can only be achieved through the ability to regulate the activity performed by the subjects, managing, on one hand, the activities' variability of internal and external conditions and, on the other hand, the effects of the activity [16].

As it is impossible to predict everything that happens; there is always a space, unknown to the designers and to the company, where operators work without it having been intended. This area of regulation is what allows the operator to reach the goals set by the task. According to these authors, if the employees did not intervene, modifying the work and influencing the organization of work, there would be many problems both in productivity and in quality. The intelligence of the working class has always been necessary in regulating the variability that is present both in work and in production. However, there are work situations where maneuvering is very limited, leaving the worker with only a few possible interventions within their operations [15].

It is in the activity that the experience and knowhow of the subject are put into practice in the form of decision making, promoting the regulation of incidents, making activity viable [3].

The maneuver margin or regulatory space which the operator has available to him so that he can reach production goals is larger or smaller, that is, it depends on the different objectives and situations which are faced.

\subsection{The organizational transformations and regu-} lation of the activity

Flexible production, while differentiating, in some respects, the traditional model from the "scientific management of work" raises the question concerning the nature of regulations in the process of working on changes to the requirements, autonomy, collective action, cooperation and coordination, which are central to the discussion of activity ergonomics.

Tasks have been increasingly demanding of initiative, communication and exchange among workers, that is, various forms in the process of action and recognition of skills [11].

Efficiency can only be reached in an organization once workers have a certain autonomy. Execution autonomy is a possibility in flexible management. However, autonomy can refer to an individual or a collective, being that if the regulation involved is determined discretion would be implied, if there were a transmutation between the initial autonomy to a granted autonomy. The actual goal of the "new rationalization" might just be the control over regulation which structures the development of the work [11].

The discretionary (la discrétion) task involves the duty of deciding, though the premises of the decision are controlled by the company; it is therefore a double constraint. In the work situation, it is the system that organizes, determines the tasks in such a way that individuals are integrated and hopefully will adapt to it.

In view of the changes in work organization, it may be noted that ergonomic analysis, traditionally related to a single worker, tends to analyze the collective action among different workers.

In collective action, communication is the central point and the arrangements are revealed through the cooperation and coordination among the workers. However, individualized actions do not cease to exist along with common actions in transformed work situations and that the actions, and hierarchies are also not absent [11].

According to the same author, cooperating is participating in a common product, through collective action, however, the purpose can be determined by the individual concerned or it can be prescribed to them. In transformed work situations, with greater flexibility, in which cooperation and coordination are developed, the constraints are also present.

For him, the coordination of the team devoted to the task is what regulates relations between the actions of cooperation in different levels of communication. The action of coordination consists in making rules to ensure a common goal, there is an "obligation to cooperate" to achieve this common purpose. The changes in the work process show that the coor- 
dination of tasks are in a relationship of reciprocity and have, as a main characteristic, by high levels of communication between workers.

Amid these changes, it is important to understand how the regulation is built through different strategies and operational methods, a fact that helps to make the regulation of work situations clearer.

\section{The case of the electrical components company}

To better analyze and expand the knowledge acquired through literary research it was decided to carry out a case study. The methodology used in the case study was the analysis of activity, as a presumption to the approach of Ergonomic Work Analysis (EWA).

For the analysis of the work situation at the company chosen for the case study, 08 visits were carried out, and the approval of the study was granted by the engineer who was and is responsible for the adoption of Lean techniques in the company.

The company studied is a factory which produces electrical and electronic components for the variety of products manufactured for the market that handles electronics, appliances and automobiles. It is one of the leaders in Brazil when it comes to electrical networks in the white line segment.

Among the products manufactured are: CDI's (ignition), power cords, electronic boards, systems and electric networks (whips). The customers are large companies that manufacture household, electronic and automotive appliances.

The company is divided into three sectors: wire factory, segmenting sector and assembly sector. There is a flow of items among the sectors previously mentioned, however stocks are intermediate.

The sector chosen for the study was the assembly of white goods, due to the use of tools of lean production system and because it presented a high rate of absenteeism, according to the clinic's nurse.

Within the assembly sector, Block A, composed of 20 assembly lines for cooling and electrical networks was selected and line SK was chosen from Block A. This line was selected because it presented the largest number of individuals with more seniority in the business, having therefore a longer involvement with the techniques of the lean production model. However, due to the rotation of shifts there was contact with different teams, that is, with people with more and less time of service at that site.
There are six workstations on line S.K.; three workstations are there to prepare the electrical grid, two workstations assemble the power grid and a workstation is there for inspection purposes (final line). At each post there is a responsible worker, and there is a relationship of inter-dependence among these workers, since their tasks involve working as a team on a production line.

For the activity analysis, systematic observations were carried out, descriptions and analysis of the operational methods adopted by operators within the regulatory areas available to them during work activities, managed by lean production system tools.

\section{Discussions and conclusions}

It is important to make clear that the literary works that were reviewed allow one to affirm that the workers who were observed in the case study, regulate their activities in a way that is similar to the situations common to the production and work organization models that are characteristic of traditional assembly lines, since some features have not disappeared, still quite used as the hierarchy, the assembly line and work in series.

Many features of the traditional model of production continue to be enforced in today's businesses. When promoting a comparison to a study of a traditional assembly [3], it can be noticed that in the company that was studied the following are still present:

-The use of techniques such as MTM (Methods Time Measurement), which calculates the time required for each motion, without considering the variability within and between individual operators.

-The separation between the management and execution, due the observation of the roles occupied by social actors involved in the processes of action;

-Prorated actions or the decomposition of the activity into a sequence of actions through which each workstation is independent from the other;

-The physical activities that are considered "light", are often underestimated and can result in significant fatigue, as reported by some operators;

-Prescribed tasks still occupy a prominent place and must be followed obligatorily, "shaping" the behaviors through limits and possibilities of actions during the work process [5];

-Problems related to the workstations and to posture are considerable and have influence on physical overloads, being that no activity is purely physical, it 
involves constant adjustments, which makes for an intense mental work;

-Anxiety is found to be present and, in the situation that is observed, not only because of the technical devices which are present and with the risk accidents, but with the company's future and the possibility of dismissal, as reported by some operators;

-During the learning process of the work, operators also need to taught to do the task within a period of time stipulated by the company, they must therefore regulate the activity in order to adapt to the new situation which also involves an increase on the mental workload during the work process;

-Absenteeism is a considerable factor found in the studies. In this case it was not possible to collect this data, but according to the operators a significant increase in absenteeism could be noticed after the introduction of the flexible working model.

The nature of the standardization of work activities characterized by organizational transformation is related to lean techniques adopted by the company which was analyzed in this case study, that influence the strategies and operational methods adopted by operators during the process. Among the aspects relevant to the nature of regulations that could be observed in work situations, we have:

-Autonomy and discretionary (la discretion) action;

-Teamwork;

-The cooperation and coordination.

In the company that was studied, in order to achieve the expected results - to produce 49 parts / hour, the operators regulate the work activity by increasing the rate / rhythm of production, that is, they accelerate the speed in which the electrical grids are assembled both individually and collectively, as noted in the analysis of the activity.

With the introduction of the so-called continuous improvements, there was a significant increase in the quantity of parts to be produced per hour. To account for this increase, operators made use of strategies such as autonomy, cooperation and coordination in order to increase the pace at certain times, when, for example, an operator realizes that he or she is ahead of schedule in his or her work while a colleague is behind schedule, taking the initiative of leaving his or her workstation in order to assist his college in making some of the steps more agile, so that they may achieve the goal and have time for internal regulation. Another example worth mentioning is the way the operator individually, increases the pace of his or her task by adopting strategies, on their own initiative, without using a template, making connections in their own hands, or by connecting multiple conductors at once in order to reduce the time spent while putting together each network that must be assembled in his or her workstation.

The analysis confirms that the written formalized tasks do not take into account the variations, however there is no indication of strategies so that the production will be fulfilled and the desired result accomplished, therefore, the operators rely on their experience and expertise to solve potential problems on the assembly line that was studied. The autonomy during the execution is shown as a privileged space for the expression and for the development of skills [11]. Another example of decision making made by operators on line SK is in checking, during the process, of small errors arising from previous posts that could be barred at the poka-yoke, with consequent delay in production, however, this often does not occur because, in a collective setting, the subjects ascertain, through the adjustment or repair, that the desired result is achieved.

As for teamwork, and the aspects related to cooperation and coordination, there is also, as example, cleanliness and organization, part of the $5 \mathrm{~S}$ tool, conducted by the workers of the workstations that were analyzed, so that there is an alternation of activities. This order of things is established by the operators themselves, acquiring the aspect of autonomy, however, as the tool and the company compels the operators into their courses of action, one may conclude that it is an example of granted discretion.

When regarding teamwork a contradiction can be perceived in the concept of the lean production model in this respect; when taking into account the number of assembly line workers, the number of prescribed tasks and time tables reduced, making teamwork impossible. This fact is documented in the analysis, since there is individualized work happening workstation, as each operator has a set of tasks that must be fulfilled for the following work station.

Today's businesses seek to overcome the rigidity of the programs, procedures and work assignments for the adoption of flexible solutions, requiring discretion to expressions of autonomy that reveal themselves as functional to the organization. The autonomy is the recognition that the system`s order builds through negotiations among all social actors and is therefore not predetermined [11].

The rotation among workstations in the same line analyzed makes possible, not only construction of multivalent attributes, but the reduction of repetitiveness in tasks, despite the similarity in the nature of prescriptions. The organization of these rotations, 
which occur every hour, is determined by the line supervisor, but the exchange of posts, that is, who goes to a specific workstation is decided by the team members who are to do the work, therefore, this involves heteronomy and group autonomy. In addition, this form of collective regulation is necessary to maintain and build this form of work organization and production, since there is a "democratization" of working conditions.

In the lean manufacturing model, the use of kaizen is an example of the use of a technique that enhances experiences, knowledge and initiative of workers, a fact that bridges the gap between management and execution. Acording to the company, some "improvements" were implemented, however, some workers, as noted in the analysis of activity, claim not to know their placements have not witnessed improvements as a result of the proposals for improvement. This as a system of ideas, in which workers believe they are actually participating in the development and implementation of products, when in reality they would only be producing what is essential and necessary to the company. Perhaps this is due to the fact that there is a clear separation between management and execution. Moreover, given the formalized prescriptions, the company expects the operators to have the same performance at their workstations, since the prescription determines the way activities ought to be carried out, the pace that must be employed, and provides the space for the activity [9].

In regard to the requirements of teamwork, involving cooperation and coordination, it is concluded that with the introduction of lean production techniques in work situations, individual regulations and actions have not ceased to happen along with collective actions.

It is also concluded that in situations of regulation of work activity, many aspects of the traditional assembly line remain present in lean assembly lines, however a new language is employed, due to the new and more flexible culture, the lean production model.

The search for efficiency through the reduction of time and personnel, the increase in the speed of the pace, the increase in the requirements regarding team work, greater autonomy, among other characteristics of the lean model, reduce the leeway of the operators and, as consequence, increase the rates of absenteeism and the need for a greater number of individual and collective strategies for the regulation of production and work.

\section{References}

[1] Bernardo, M. H. Trabalho duro, discurso flexível: Uma análise das contradições do toyotismo a partir da vivência de trabalhadores. São Paulo, editora Expressão Popular, 2009.

[2] Dal Rosso, S.D. A regulação social do trabalho. In: FERREIRA, M. C., Dal Rosso, S. A regulação social do trabalho. Brasília, Paralelo 15, 2003, p.15-20.

[3] Daniellou, F., Laville, A., Teiger, C. Ficção e realidade do trabalho operário. Revista Brasileira de Saúde Ocupacional, 68(17): 48-54, 1989.

[4] Falzon, P. Natureza, objetivos e conhecimentos da ergonomia - elementos de uma análise congnitiva da prática. In: Falzon, P. Ergonomia. São Paulo, editora Blucher, 2007, p. 03-19.D.F.

[5] Ferreira, M. C. O sujeito forja o ambiente, o ambiente "forja" o sujeito: Mediação indivíduo-ambiente em ergonomia da atividade. In: Ferreira, M. C., Rosso, S. D. A regulação social do trabalho. Brasília, Paralelo 15, 2003, p. 21-46.

[6] Fleury, A.C.C. Organização do trabalho na indústria: recolocando a questão nos anos 80. In Fleury, M.T.L., Fisher, R.M. Processo de relações do trabalho no Brasil. São Paulo: Atlas S.A., 1985, p.51-66.

[7] Giesta, L. C., Maçada, A. C. G. Análise do Sistema de Produção Enxuta (SPE) na Percepção dos funcionários: O caso de uma empresa de Tratores e Retroescavadeiras. In: ENEGEP, 12, 2002, Curitiba, Anais eletrônico... Curitiba: 2002, disponível em: $<$ http://www.ea.ufrgs.br/professores/acgmacada/PUBS/SPE.P DF> Acesso em: 26/06/2008.

[8] Guérin, F., et al. Compreender o trabalho para transformá-lo: a prática da ergonomia. $1^{\mathrm{a}}$ Ed. São Paulo: Edgard Blücher, 2001.

[9] Koler, H.D. La máquina que cambió el mundo cumplió diez años. Sociología del Trabajo. Madrid, n.41, p. 75-100, 2000/2001.

[10] Lima, F.P.A. Fundamentos teóricos da metodologia e prática de análise ergonômica do trabalho. Texto de divulgação interna do DEP-UFMG, 1998.

[11] Maggi, B. Do agir organizacional: Um ponto de vista sobre o trabalho, o bem estar, a aprendizagem. $1^{\text {a }}$ Ed. São Paulo: Edgard Blücher, 2006.

[12] Pontes, S.K. Produção Enxuta e Saúde do Trabalhador: Um Estudo de Caso. 136f. Dissertação (Mestrado), Programa de Pós-Graduação em Engenharia de Produção, Universidade Federal de São Carlos - UFSCar, São Carlos, 2006.

[13] Salermo, M.S. Projetos de organizações integradas e flexíveis - processos, grupos e gestão democrática via espaços. São Paulo: Atlas, 1999. p. 121-161.

[14] Smith, V. New forms of work organization. Annual Review of Sociology. V. 23, p.315-339, August 1997. Disponível em: $<$ http://arjournals.annualreviews.org/doi/pdf/10.1146/annurev. soc.23.1.315? cookieSet=1> Acesso em 26/06/2008.

[15] Snelwar, L. I., Mascia, F. L. A inteligência (não reconhecida) do trabalho. In: Arbix, G., Zilbovicius, M. De JK a FHC: a Reinvenção dos carros. São Paulo, Ed. Scritta, 1997, p. $205-$ 235.

[16] Tersac, G., Maggi, B. O Trabalho e a Abordagem Ergonômica. In: Daniellou, F. A ergonomia em busca de seus princípios debates epistemológicos.

[17] Turato Junior, E. D., Canêo, L.C., Fernandes, J.M. Reestruturação produtiva: notas e reflexões sobre o toyotismo e os principais impactos no mundo do trabalho. XII SIMPEP Bauru, SP, Brasil, 07 a 09 de novembro de 2005.

[18] Womack, J.P.; Jones, D.T.; Roos, D. A máquina que mudou o mundo. 1.ed. Rio de Janeiro: Campus, 1992. 